\title{
СИНДРОМ ЕНДОГЕННОЇ ІНТОКСИКАЦІЇ В ЩУРІВ ІЗ ГОСТРИМ ПОШИРЕНИМ ПЕРИТОНІТОМ НА ТЛІ МЕРКАЗОЛІЛІНДУКОВАНОГО ГІПОТИРЕОЗУ
}

Вступ. Зростання ендогенного токсикозу відбувається тоді, коли інтенсивність надходження токсичних продуктів метаболізму різко збільшена або ж коли пригнічується активність антитоксичної системи чи елімінація токсичних метаболітів. При різних патологічних станах, коли продукти природних відходів організму з'являються у великій кількості в біологічних середовищах, а також коли агресивні компоненти перевищують можливості їх біотранссрормації, розвивається синдром ендогенної інтоксикації.

мета дослідження - вивчити вплив зниженого продукування тиреоїдних гормонів на показники ендогенної інтоксикації щурів із гострим поширеним перитонітом.

Методи дослідження. У роботі використовували білих щурів лінії Вістар. Гіпотиреоз моделювали шляхом введення мерказолілу в дозі 25 мг/кг протягом 21-їдоби, гострий поширений перитоніт - введення 0,5 мл 10 \% профрільтрованої калової суспензії в черевну порожнину піддослідних тварин. Визначали молекули середньої маси, еритроцитарний та лейкоцитарний індекси інтоксикації, рівень циркулюючих імунних комплексів, катепсину D.

Результати й обговорення. Встановлено, що гіпотиреоз в експериментальних тварин, у яких моделювали гострий поширений каловий перитоніт, супроводжувався більш вираженим, ніж в евтиреоїдних щурів, зростанням показників ендотоксикозу - середньомолекулярних пептидів, еритроцитарного та лейкоцитарного індексів інтоксикації, циркулюючих імунних комплексів та гіршою динамікою їх нормалізації. Спостерігали фразові зміни активності катепсину D.

Висновок. Дефріцит йодовмісних гормонів щитоподібної залози супроводжується достовірним зростанням показників, що характеризують синдром ендогенної інтоксикації, порівняно з евтиреоїдними тваринами, що може бути однією з причин розвитку поліорганної недостатності за цих умов.

КЛЮЧОВІ СЛОВА: поширений перитоніт; мерказоліліндукований гіпотиреоз; ендогенна інтоксикація.

ВСТУП. Зростання ендогенного токсикозу відбувається тоді, коли інтенсивність надходження токсичних продуктів метаболізму різко збільшена або ж коли пригнічується активність антитоксичної системи чи елімінація токсичних метаболітів. При різних патологічних станах, коли продукти природних відходів організму з'являються у великій кількості в біологічних середовищах, а також коли агресивні компоненти перевищують можливості їх біотрансформації, розвивається синдром ендогенної інтоксикації (CEI) [1]. Слід визнати, що ендогенний токсикоз $\epsilon$ "супутньою тінню" критичних ситуацій, але це не означає, що він не виникає без критичного стану. Найбільш важливим фрактом $€$ те, що (с Р. І. Верба, І. М. Кліщ, 2017. ендогенний токсикоз та критична ситуація пов'язані між собою і лікування одного без ліквідації іншого стає неможливим [2-5].

Незважаючи на схожість патогенезу CEI, при кожній нозологічній формі він має певні специфрічні ознаки $[1,6]$. Перитоніт умовно можна назвати класичною моделлю СЕI, тому його доцільно розглянути як базову модель даного стану. При цьому виділяють три компоненти, що беруть участь у фрормуванні CEI при перитоніті: мікробіологічний, біохімічний (метаболічний) та імунологічний.

Гіпотиреоз посідає одне з провідних місць у структурі ендокринної патології. Поширеність субклінічного гіпотиреозу в популяції досягає 10-12 \%, маніфестного - варіює від 0,2 до 2,0 \% 
[7]. Знижене продукування тиреоїдних гормонів впливає на функцію і стан багатьох органів і систем, зокрема імунної та антиоксидантної, що суттєво впливає на перебіг патологічних процесів за цих умов [8, 9]. Перебіг перитоніту на тлі зниження функції щитоподібної залози має свої особливості. Дія екзо- й ендогенних патогенів втягує в біологічну реакцію запалення не тільки імунокомпетентні органи, але і нейросекреторні клітини гіпоталамуса, які запускають перебудову функції ендокринної системи, спрямованої на адаптацію організму до умов патологічного процесу [10].

3 метою вивчення ступеня ендотоксикозу, що відіграє суттєву роль у перебігу запального процесу, ми використали модель гострого поширеного перитоніту (ГПП) на тлі експериментального гіпотиреозу.

Оскільки стан і динаміка показників ендогенної інтоксикації залежать від інтенсивності катаболічних процесів в ураженій тканині та швидкості елімінації утворених продуктів $[11,12]$, ми поставили перед собою мету дослідити вплив зниженого продукування тиреоїдних гормонів на показники ендогенної інтоксикації щурів із гострим поширеним перитонітом.

МЕТОДИ ДОСЛІДЖЕННЯ. Для вивчення особливостей перебігу гострого перитоніту на тлі гіпотиреозу використовували білих щурів-самців лінії Вістар, яких утримували на стандартному раціоні віварію при вільному доступі до води відповідно до вимог Правил проведення робіт з використанням експериментальних тварин [13]. У кожну дослідну групу методом випадкової вибірки включили по 12 тварин масою

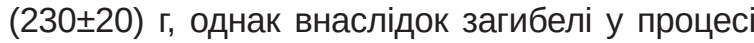
експерименту їх кількість у групах на момент евтаназії була різною. Всього у дослідженні використано 120 щурів.

Гіпотиреоз моделювали шляхом щоденного введення per os за допомогою зонда фрармакопейного тиреостатика мерказолілу (“Здоров'я", Україна) в дозі 25 мг/кг протягом 21-ї доби [14, 15]. Повноту досягнення гіпотиреозу контролювали, визначаючи концентрацію трийодтироніну і тироксину в сироватці крові, а також за динамікою маси тварин та їх рухової активності.

Вплив гіпотиреозу на перебіг ГПП вивчали на моделі, запропонованій В. А. Лазаренком та ін. (2008) [16], він близький за етіологічними чинниками, клінічними проявами і фразністю перебігу до аналогічного процесу в людини та дозволяє отримувати загибель тварин, яка $€$ прийнятною для проведення динамічного дослідження протягом 10-ти діб. Це забезпечується введенням 0,5 мл 10 \% профрільтрованої калової суспензії в черевну порожнину піддослідних щурів. Суспензію отримували шляхом змішування ізотонічного розчину і калу зі сліпої кишки 2-3 інтактних тварин, потім її двічі фрільтрували через подвійний шар марлі. Одержану суспензію не пізніше ніж через 20 хв після приготування вводили інтактним тваринам пункційним способом. Щоб уникнути пошкодження внутрішніх органів при введенні калової суспензії в черевну порожнину, щурів тримали вертикально, каудальним кінцем вгору. Методом пункції вентральної стінки в центрі середньої лінії живота, направляючи кінець голки по черзі у праве і ліве підребер'я, праву та ліву клубові ділянки, вводили однакову кількість калової суспензії.

Експериментальних тварин поділили на чотири групи:

- інтактні тварини, яким перорально вводили дистильовану воду протягом 21-ї доби;

- тварини, в яких моделювали гіпотиреоз шляхом перорального введення мерказолілу в дозі 25 мг/кг протягом 21-ї доби;

- тварини, в яких моделювали гострий каловий перитоніт;

- тварини, в яких моделювали гострий каловий перитоніт на тлі попередньо змодельованого гіпотиреозу.

Для дослідження використовували цільну кров, сироватку крові та гомогенат печінки. Тварин декапітували під тіопенталовим наркозом через 24 год, на 4-ту, 7-му і 10-ту доби від моменту початку моделювання перитоніту.

Вміст загального тироксину і загального трийодтироніну в сироватці крові визначали імунофлуоресцентним методом з використанням стандартних тест-наборів "Immulite 1000". Концентрацію гормонів виражали в пмоль/л.

Ступінь вираження ендотоксемії оцінювали за вмістом молекул середньої маси (МСM) у сироватці крові, де $\mathrm{MCM}_{1}$ - це вміст молекул середньої маси, визначений при довжині хвилі 254 нм, а МСм - при довжині хвилі 280 нм [11], а також за вираженням пошкодження еритроцитарної мембрани розраховували еритроцитарний індекс інтоксикації (ЕII) [17]. Вміст циркулюючих імунних комплексів (ЦІК) у сироватці крові визначали шляхом преципітації їх розчином поліетиленгліколю-6000 [18]. Лейкоцитарний індекс інтоксикації (ЛІІ) визначали за фрормулою, запропонованою Я. Я. Кальф-Калісром у модифрікації Б. А. Рейса [19].

Для приготування гомогенату тканину печінки розтирали за допомогою гомогенізатора при $4{ }^{\circ} \mathrm{C}$ і суспендували в 9-ти об'ємах 0,25 М розчину цукрози з 0,001 М етилендіамінтетраоцтовою кислотою (ЕДТА), рН 7,4. Сполучнотканинні елементи, які залишились у середовищі, ви- 
даляли шляхом центрифругування (1000 об./хв протягом 3 хв) при охолодженні. Надосадову частину гомогенату печінки використовували для визначення. Активність катепсину D у гомогенаті тканини печінки визначали методом Дингла [20] у модисрікації [21] за гідролізом гемоглобіну при $\mathrm{pH} 3,2$. Активність ферменту виражали в мкМ тирозину/(мг білкахгод).

Статистичну обробку цифрових даних здійснювали за допомогою програмного забезпечення Excel та STATISTICA з використанням параметричних і непараметричних методів оцінки отриманих даних. Для всіх показників розраховували значення середньої арифрметичної вибірки (М), її дисперсії і помилки середньої (m). Достовірність різниці значень між незалежними кількісними величинами визначали при нормальному розподілі за t-критерієм Стьюдента, в інших випадках - за допомогою U-критерію МаннаУїтні (достовірними вважали відмінності при $p<0,05)$.

РЕЗУЛЬТАТИ Й ОБГОВОРЕННЯ. ДЛЯ ОЦінКИ фрункціонального стану щитоподібної залози при моделюванні гіпотиреозу було визначено концентрацію тиреоїдних гормонів у крові. Концентрація загального тироксину в здорових щурів склала $(17,70 \pm 0,58)$ пмоль/л, а у тварин, яким вводили мерказоліл, показник знизився у 2,9 раза і становив $(8,96 \pm 0,26)$ пмоль/л. Концентрація загального трийодтироніну в інтактних тварин склала $(6,30 \pm 0,14)$ пмоль/л, а після введення мерказолілу зменшилась у 2 рази від показника інтактних щурів і становила $(3,09 \pm 0,08)$ пмоль/л. Ми спостерігали також суб'єктивні ознаки гіпотиреозу - зменшення рухливості, інтенсивніше, ніж у інтактних тварин, збільшення маси тіла, зміни шерсті. Це вказувало на розвиток у щурів явищ гіпотиреозу внаслідок тривалого введення мерказолілу в дозі 25 мг/кг.

Аналіз отриманих результатів експериментальних досліджень показав, що вже саме моделювання гіпотиреозу призвело до зростання ступеня ендотоксемії (табл.). Зокрема, вміст молекул середньої маси, який визначали при довжині хвилі $\lambda=254$ нм, становив 146,5 \% від рівня контрольних тварин, а при довжині хвилі $\lambda=280-128 \%$. На $21 \%$ зріс також показник EII та на $22 \%$ - ЛІІ. Достовірне зменшення концентрації катепсину D (85 \% від норми) свідчило про те, що причиною цього може бути зниження катаболічних процесів за умов десріциту тиреоїдних гормонів. 3 тієї ж причини збільшився вміст ЦІК - 116 \% від рівня інтактних тварин. Це збігається з результатами інших дослідників, які також вказують на суттєве зниження катаболічних процесів за умов десріциту тиреоїдних гормонів $[7,8]$.

Таблиця - Показники активності вільнорадикальних процесів у крові й печінці щурів із гострим перитонітом на тлі гіпотиреозу (M士m)

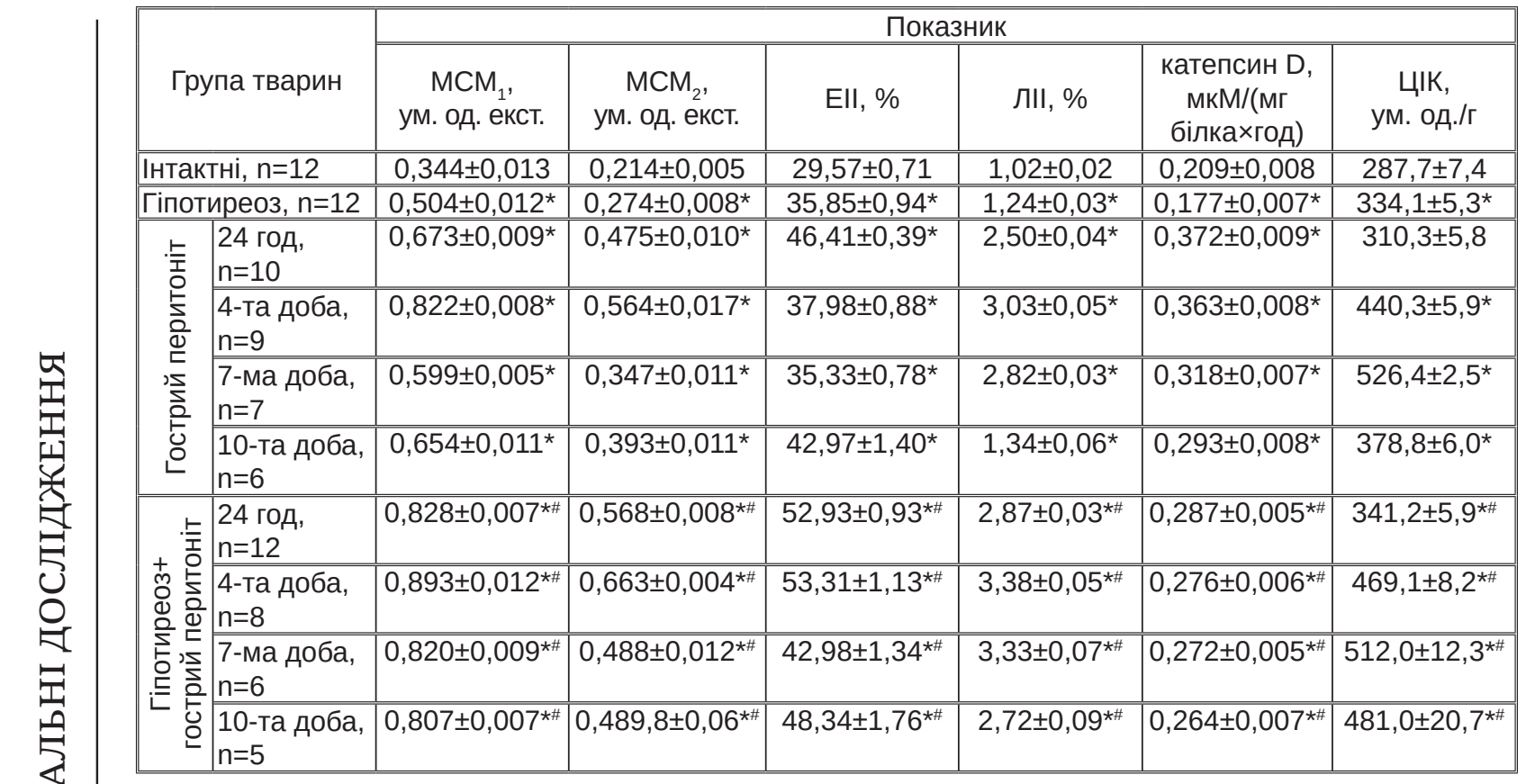

Примітки:

1. * - зміни показників евтиреоїдних і гіпотиреоїдних тварин із гострим перитонітом достовірні відносно показників інтактних щурів.

2. \# - зміни показників гіпотиреоїдних тварин із гострим перитонітом достовірні відносно показників евтиреоїдних щурів у відповідні доби дослідження. 
Моделювання ГПП супроводжувалось суттєвим зростанням ендотоксемії. Зокрема, вже через 24 год від моменту введення калової суміші вміст МСМ $_{1}$ був достовірно вищим від нормальних значень і склав $196 \%$ від рівня інтактних тварин. Показник $\mathrm{MCM}_{2}$ зріс ще більше і становив $222 \%$ від норми, що вказувало на інтенсивніше накопичення ароматичних сполук. Засріксовано і значне зростання еритроцитарного та лейкоцитарного індексів інтоксикації: EII склав 157 \%, а ЛІІ - 245 \% від рівня здорових щурів, що свідчило про більшу чутливість цього показника в ранні терміни перитоніту. Рівень ЦІК у цей термін експерименту дещо зріс, однак показник був недостовірним порівняно 3 контрольними тваринами. Суттєве підвищення вмісту катепсину D, яке можна пояснити більш масивною міграцією нейтрофрілів у вогнище ураження, вказувало на інші причини зростання ендотоксемії за даних умов - імовірно, зниження елімінації деградованих молекул внаслідок порушення кровотоку та фрільтраційної здатності нирок.

На 4-ту добу після моделювання ГПП ступінь ендогенної інтоксикації був ще вищим. Зокрема, вміст середньомолекулярних пептидів зріс, відповідно, у 2,4 та 2,6 раза, Ell - в 1,3 раза, а ЛII у 2,9 раза. Суттєвіше збільшився рівень ЦІК - в 1,5 раза. Водночас зменшувався вміст катепсину D порівняно з попереднім терміном спостереження.

У подальшому у тварин, які вижили, показники дещо покращувались і до 10-ї доби спостереження вміст $\mathrm{MCM}_{1}$ перевищував рівень інтактних тварин в 1,9 раза, MCM $_{2}$ - в 1,8 раза. Значно нижчими, порівняно з попередніми термінами спостереження, були також ЛІІ (131 \%) та ЦІК (132 \%) від рівня інтактних щурів. Зменшився також вміст катепсину D. Однак показник EII був вищим, ніж на 4-ту і 7-му доби спостереження, і становив $145 \%$ від норми.

У щурів, у яких ГПП моделювали на тлі гіпотиреозу, ступінь ендотоксемії був значно більшим, ніж в евтиреоїдних тварин, в яких моделювали ГПП. Зокрема, вже через 24 год від момен- ту введення калової суміші вміст $\mathrm{MCM}_{1}$ зріс у 2,4 раза відносно інтактних тварин та був на $23 \%$ вищим, ніж в евтиреоїдних щурів із ГПП. Ще більше зростання мало місце стосовно $\mathrm{MCM}_{2}-$ відповідно, у 2,7 раза відносно інтактних тварин та на 120 \% відносно евтиреоїдних щурів. Показник Ell склав 179 \%, а ЛII - 281 \% від норми, при цьому збільшення вмісту катепсину D було незначним - 137 \% від норми. Рівень ЦІК становив 118 \% від норми. До 4-ї доби показники, що характеризують стан ендогенної інтоксикації, продовжували зростати. Зокрема, вміст МСМ склав, відповідно, 260 і 310 \%, достовірно перевищуючи також аналогічні показники евтиреоїдних тварин із ГПП. Аналогічне зростання зафріксовано і щодо EII й ЛII - відповідно, 180 та 331 \% від норми. Значно вищим був і показник ЦІК 163 \% від норми. Показник катепсину D практично не змінився порівняно з попереднім терміном спостереження, однак був достовірно меншим від аналогічного показника евтиреоїдних тварин.

У подальші терміни спостереження, на відміну від групи евтиреоїдних щурів, у яких відзначали певну стабілізацію рівня ендотоксемії, в гіпотиреоїдних тварин показники майже не змінювались, а деякі навіть погіршувались та до 10-ї доби спостереження достовірно відрізнялись від показників як інтактних тварин, так і щурів з нормальним рівнем тиреоїдних гормонів, у яких моделювали ГПП.

Звертає на себе увагу той сракт, що до 10-ї доби протеазна активність катепсину D знизилась на 9 \% від початку експерименту, тоді як у групі евтиреоїдних тварин ми відмітили суттєве зниження активності катепсину D за аналогічний період - на $40 \%$.

ВИСНОВОК. Десріцит йодовмісних гормонів щитоподібної залози супроводжується достовірним зростанням показників, які характеризують синдром ендогенної інтоксикації, порівняно 3 евтиреоїдними тваринами, що може бути однією з причин розвитку поліорганної недостатності за цих умов.

\section{СПИСОК ЛІТЕРАТУРИ}

1. Остапенко В. А. К патогенезу синдрома эндогенной интоксикации / В. А. Остапенко // Эндогенные интоксикации. - СПб., 1994. - С. 43.

2. Распространенный гнойный перитонит / В. В. Бойко, И. Л. Криворучко, С. И. Тесленко, А. В. Сивожелезов. - Х. : Прапор, 2008. - 278 с.

3. Дзюбановський І. Я. Синдром поліорганної недостатності та його корекція у хворих на гострий поширений перитоніт / І. Я. Дзюбановський, Б. О. Мігенько // Укр. Журн. Хірургії. - 2009. - № 2. - С. 56-59.

4. Костюченко А. Л. Интенсивная терапия послеоперационной раневой инфекции и сепсиса / А. Л. Костюченко, А. Н. Бельских, А. Н. Тулупов. - СПб. : Фолиант, 2000. - 448 с.

5. Подунай Ю. А. Возрастная динамика активности катепсинов и содержания среднемолекулярных 
пептидов в мышцах морского ерша / Ю. А. Подунай, И. Н. Залевская, И. И. Руднева // Ученые записки Таврического нац. ун-та им. В. И. Вернадского. Серия “Биология, химия". - 2009. - 22 (61), № 4. - С. 128-134.

6. Нетюхайло Л. Г. Молекули середньої маси маркери ендогенної інтоксикації при експериментальній опіковій хворобі / Л. Г. Нетюхайло // Сучасні проблеми токсикології. - 2005. - № 3. - С. 43-46.

7. Вацеба А. О. Епідеміологія захворювань щитоподібної залози в умовах йодної недостатності / А. О. Вацеба, В. М. Гаврилюк, В. І. Паньків // Лікар. справа. - 2002. - № 1. - С. 31-33.

8. Паньків В. І. Практична тиреоїдологія : монографрія / В. І. Паньків. - Донецьк : Заславський О. Ю., 2011. - 224 c.

9. Tenorio-Velazquez V. M. Hypothyroidism attenuates protein tyrosine nitration, oxidative stress and renal damage induced by ischemia and reperfusion: effect unrelated to antioxidant enzymesactivities / V. M. TenorioVelazquez, D. Barrera, M. Franco // BMC Nephrol. 2005. - 11, № 6. - P. 12.

10. Boelen A., Kwakkel J., Platvoetter Schiphorst M. et al. Interleukin-18, a proinflammatory cytokine, contributes to the pathogenesis of non-thyroid al illness mainly via the central part of the hypothalamus-pituitarythyroid axis // Eur. J. Endocrinol. - 2004. - 151, № 4. P. 497-502.

11. Габриэлян Н. И. Опыт использования показателя средних молекул в крови для диагностики нефрологических заболеваний у детей / Н. И. Габриэлян, В. И. Липатова // Лаб. дело. - 1984. - № 3. С. 138-140.

12. Малахова М. Я. Методы биохимической регистрации эндогенной интоксикации / М. Я. Малахова // Эффрерентная терапия. - 1995. - 1, № 1. - С. 61-64.

\section{REFERENCES}

1. Ostapenko, V.A. (1994). K patogenezu sindroma endogennoy intoksikatsii. Endogennye intoksikatsii [To the pathogenesis of the syndrome of endogenous intoxication. Endogenous intoxications]. Saint-Petersburg [in Russian].

2. Boyko, V.V., Kryvoruchko, I.L., Teslenko, S.I., \& Sivozhelezov, A.V. (2008). Rasprostranennyy gnoynyy peritonit [Common purulent peritonitis]. Kharkov: Prapor [in Russian].

3. Dziubanovskyi, I.Ya., \& Mihenko, B.O. (2009). Syndrom poliorhannoi nedostatnosti ta yoho korektsiia u khvorykh na hostryi poshyrenyi perytonit [Organ failure syndrome and its correction in patients with acute peritonitis]. Ukrainskyi zhurnal khirurhii - Ukrainian Journal of Surgery, 2, 56-59 [in Ukrainian].

4. Kostyuchenko, A.L., Belskikh, A.N., \& Tulupov, A.N. (2000). Intensivnaya terapiya posleoperatsionnoy ranevoy infektsii i sepsisa [Intensive therapy of postoperative wound infection and sepsis]. Saint-Petersburg: Foliant [in Russian].

5. Podunay, Yu.A., Zalevskaya, I.N., \& Rudneva, I.I. (2009). Vozrastnaya dinamika aktivnosti katepsinov i
13. Науково-практичні рекомендації з утримання лабораторних тварин та роботи з ними / Ю. М. Кожем'якін, О. С. Хромов, М. А. Філоненко, Г. А. Сайфретдінова. - К. : Авіцена, 2002. - 156 с.

14. Ром-Бугославська О.С. Доклінічне вивчення тиреостатичних та тиреоїдстимулюючих засобів / О. С. Ром-Бугославська, Т. С. Божко, І.В.Комарова // Доклінічні дослідження лікарських засобів : метод. рек. - К., 2001. - С. 409-420.

15. Isman C.A. Methimazole-induced hypothyroidism in rats ameliorates oxidative injury in experimental colitis / C.A. Isman, B.C. Yegen, I. Alican // J. Endocrinol. 2003. - 177, № 3. - P. 471-476.

16. Экспериментальная модель распространенного калового перитонита / В. А. Лазаренко, В.А.Липатов, Ю. Ю. Блинков, Д. В. Скориков // Человек и его здоровье. - 2008. - № 4. - С. 128-132.

17. Тогайбаев А. А. Метод определения эндогенной интоксикации / А. А. Тогайбаев, А. В. Кургузкин, И. В. Рикун // Лаб. дело. - 1988. - № 9. - С. 22-24.

18. Гриневич Ю. А. Определение имунных комплексов в крови онкологических больных / Ю. А. Гриневич, А. М. Алферов // Лаб. дело. - 1981. - № 8. C. 493-495.

19. Сперанский И. И. Общий анализ крови - все ли его возможности исчерпаны? Интегральные индексы интоксикации как критерии оценки тяжести течения эндогенной интоксикации, ее осложнений и эфрфективности проводимого лечения / И. И. Сперанский, Г. Е. Самойленко, М.В.Лобачева // Здоровье Украины. - 2009. - № 6 (19). - С. 51-57.

20. Дингл Дж. Методы исследования / Дж. Дингл. М. : Мир, 1980. - 344 с.

21. Wiederanders B. Accumulation of inactive cathepsin D in old rats / B. Wiederanders, B. Oelke. // Mech. Ageing Dev. - 1982. - 24. - № 3. - P. 265-271. soderzhaniya srednemolekulyarnykh peptidov v myshtsakh morskogo yersha [Age dynamics of cathepsin activity and content of medium-molecular peptides in sea-buckthorn muscles]. Uchenyye zapiski Tavricheskogo natsionalnogo universiteta im. V.I. Vernadskogo. Seriya "Biologiya, khimiya" - Scientific notes of the Taurida National University named after V.I. Vernadsky. Series "Biology, Chemistry", 4 (61), 128-134 [in Russian].

6. Netiukhailo, L.H. (2005). Molekuly serednoi masy markery endohennoi intoksykatsii pry eksperymentalnii opikovii khvorobi [The average molecular weight markers of endogenous intoxication in experimental burn disease]. Suchasni problemy toksikolohii - Modern Problems of Toxicology, 3, 43-467. [In Ukrainian].

7. Vatseba, A.O., Havryliuk, V.M., \& Pankiv, V.I. (2002) Epidemiolohiia zakhvoriuvan shchytopodibnoi zalozy v umovakh yodnoi nedostatnosti [Epidemiology of thyroid disease in terms of iodine deficiency]. Likarska sprava - Medical Practice, 1, 31-33 [in Ukrainian].

8. Pankiv, V.I. (2011). Praktychna tyreoidolohiia : monohrafiia [Practical thyroidology : monography]. Donetsk [in Ukrainian]. 
9. Tenorio-Velazquez, V.M., Barrera, D., \& Franco, M. (2005). Hypothyroidism attenuates protein tyrosine nitration, oxidative stress and renal damage induced by ischemia and reperfusion: effect unrelated to antioxidant enzymes activities. BMC Nephrol., 11 (6), 12.

10. Boelen, A., Kwakkel, J., \& Platvoetter Schiphorst M. (2004) Interleukin-18, a proinflammatory cytokine, contributes to the pathogenesis of non-thyroid al illness mainly via the central part of the hypothalamuspituitary-thyroid axis. Eur. J. Endocrinol., 151 (4), 497-502.

11. Gabrielyan, N.I., \& Lipatova, V.I. (1984). Opyt ispolzovaniya pokazatelya srednikh molekul v krovi dlya diagnostiki nefrologicheskikh zabolevaniy u detey [Experience in using the indicator of average molecules in the blood for the diagnosis of nephrologic diseases in children]. Laboratornoye delo - Laboratory Work, 3, 138140 [in Russian].

12. Malakhova, M.Ya. (1995). Metody biokhimicheskoy registratsii endogennoy intoksikatsii [Methods of biochemical registration of endogenous intoxication]. Efferentnaya terapiya - Efferent Therapy, 1, (1), 61-64 [in Russian].

13. Kozhemiakin, Yu.M., Khromov, O.S., Filonenko, M.A., \& Saifetdinova, H.A. (2002). Naukovo-praktychni rekomendatsii z utrymannia laboratornykh tvaryn ta roboty z nymy [Scientific and practical advice on keeping laboratory animals and work with them]. Kyiv: Avitsena [in Ukrainian].

14. Rom-Buhoslavska, O.S., Bozhko, T.S., \& Komarova, I.V.(2001) Doklinichne vyvchennia tyireostatychnykh ta tyreoid-stymuliuiuchykh zasobiv [Pre-clinical study and thyreostatic tyreoyid-stimulants drugs]. Doklinichni doslidzhennia líkarskykh zasobív: metod. rekomendatsii Pre-clinical studies of drugs: guidelines [in Ukrainian].
15. Isman, C.A., Yegen, B.C., \& Alican, I. (2003). Methimazole-induced hypothyroidism in rats ameliorates oxidative injury in experimental colitis. J. Endocrinol., 177 (3), 471-476.

16. Lazarenko, V.A., Lipatov, V.A., Blinkov, Yu.Yu., \& Skorikov, D.V. (2008). Eksperimentalnaya model rasprostranennogo kalovogo peritonita [Experimental model of widespread fecal peritonitis] Chelovek $i$ yego zdorovye - Man and his health, 4, 128-132 [in Russian].

17. Togaybayev, A.A., Kurguzkin, A.V. \& Rikun, I.V. (1988). Metod opredeleniya endogennoy intoksikatsii [Method for the determination of endogenous intoxication]. Laboratornoye delo - Laboratory Work, 9, 22-24 [in Russian].

18. Grinevich, Yu.A., \& Alferov, A.M. (1981). Opredeleniye imunnykh kompleksov $v$ krovi onkologicheskikh bolnykh [Determination of immune complexes in the blood of cancer patients]. Laboratornoye delo - Laboratory work, 8, 493-495 [in Russian].

19. Speranskiy, I.I., Samoylenko, G.Ye., \& Lobacheva, M.V. (2009). Obshchiy analiz krovi - vse li yego vozmozhnosti ischerpany? Integralnyye indeksy intoksikatsii kak kriterii otsenki tyazhesti techeniya endogennoy intoksikatsii, yeye oslozhneniy i effektivnosti provodimogo lecheniya [The general or common analysis of a blood whether all its possibilities are settled or exhausted? Integral indices of intoxication as criteria for assessing the severity of the course of endogenous intoxication, its complications and the effectiveness of the ongoing treatment]. Zdorovye Ukrainy - Health of Ukraine, 6 (19),51-57 [in Russian].

20. Dingl Dzh. (1980). Metody issledovaniya [Methods of research]. Moscow: Mir [in Russian].

21. Wiederanders, B., \& Oelke, B. (1982). Accumulation of inactive cathepsin D in old rats. Mech. Ageing Dev., 24 (3), 265-271.

\section{СИНДРОМ ЭНДОГЕННОЙ ИНТОКСИКАЦИИ У КРЫС С ОСТРЫМ РАСПРОСТРАНЕННЫМ ПЕРИТОНИТОМ НА ФОНЕ МЕРКАЗОЛИЛИНДУЦИРОВАННОГО ГИПОТИРЕОЗА}

\section{Резюме}

Вступление. Рост эндогенного токсикоза происходит тогда, когда интенсивность поступления токсических продуктов метаболизма резко увеличена или когда подавляется активность антитоксической системы или элиминация токсических метаболитов. При различных патологических состояниях, когда продукты природных отходов организма появляются в большом количестве в биологических средах, а также когда агрессивные компоненты превышают возможности их биотрансформации, развивается синдром эндогенной интоксикации.

Цель исследования - изучить влияние сниженного продуцирования тиреоидных гормонов на показатели эндогенной интоксикации крыс с острым распространенным перитонитом. 
Методы исследования. В работе использовали белых крыс линии Вистар. Гипотиреоз моделировали путем введения мерказолила в дозе 25 мг/ка в течение 21-х суток, острый распространенный перитонит - введения 0,5 мл 10 \% профильтрованной каловой суспензии в брюшную полость подопытных животных. Определяли молекулы средней массы, эритроцитарный и лейкоцитарный индексы интоксикации, уровень циркулирующих иммунных комплексов, катепсина D.

Результаты и обсуждение. Установлено, что гипотиреоз у экспериментальных животных, у которых моделировали острый распространенный каловый перитонит, сопровождался более выраженным, чем в эутиреоидных крыс, возрастанием показателей эндотоксикоза - среднемолекулярных пептидов, эритроцитарного и лейкоцитарного индексов интоксикации, циркулирующих иммунных комплексов и худшей динамикой их нормализации. Наблюдали фразовые изменения активности катепсина $D$.

Вывод. Дефицит йодсодержащих гормонов щитовидной железы сопровождается достоверным возрастанием показателей, характеризующих синдром эндогенной интоксикации, по сравнению с эутиреоцдными животными, что может быть одной из причин развития полиорганной недостаточности в этих условиях.

КЛЮЧЕВЫЕ СЛОВА: распространенный перитонит; мерказолилиндуцированный гипотиреоз; эндогенная интоксикация.

R. I. Verba, I. M. Klishch

\section{SYNDROME OF ENDOGENOUS INTOXICATION IN RATS WITH ACUTE DISTRIBUTED PERITONITIS ON THE BACKGROUND OF MERCAZOLILUM-INDUCED HYPOTHYROIDISM}

\section{Summary}

Introduction. The growth of endogenous toxicosis occurs when the admission intensity of toxic metabolic products increased sharply, or when the activity of antitoxic systems or elimination of toxic metabolites inhibits. The syndrome of endogenous intoxication develops at various pathological conditions, when the number of natural waste products of the body, which appeared in large quantities in biological environments, as well as aggressive components exceeds the capacity of biotransformation.

The aim of the study - to learn the effect of reduced production of thyroid hormones on the indices of endogenous intoxication of rats with acute widespread peritonitis.

Research Methods. The study used white Wistar rats. Hypothyroidism was simulated by the administration of Mercazolil at a dose of $25 \mathrm{mg} / \mathrm{kg}$ for 21 days. Acute widespread peritonitis was simulated by injecting $0.5 \mathrm{ml}$ of $10 \%$ filtered fecal suspension into the abdominal cavity of the studied animals. The determination of molecules of average weight, erythrocyte and leukocyte indices of intoxication, level of circulating immune complexes and catepsin D was carried out.

Results and Discussion. It was established that the presence of hypothyroidism in experimental animals to which was simulated acute widespread faecal peritonitis was accompanied by, more expressed than in euthyroid rats, increase in endotoxicosis - medium molecular weight peptides, erythrocyte and leukocyte indices of intoxication, circulating immune complexes and worse dynamics of their normalization. Phase changes in cathepsin $D$ activity were observed.

Conclusions. Deficiency of iodine-containing thyroid hormones is accompanied by a reliable increase in the indices characterizing the syndrome of endogenous intoxication in comparison with the euthyroid animals. This may be one of the reasons for the development of multiple organ failure in these conditions.

KEY WORDS: widespread peritonitis; hypothyroidism; endogenous intoxication.

Отримано 20.04.17

Адреса для листування: І. М. Кліщ, Тернопільський державний медичний університет імені І. Я. Горбачевського, майдан Волі, 1, Тернопіль, 46001, Україна, e-mail: klishch@tdmu.edu.ua. 